\title{
PKM DESA LEMAHBANG DEWO ROGOJAMPI KABUPATEN BANYUWANGI NORMALISASI SALURAN AIR HUJAN DAN GREY WATER (AIR KOTOR RUMAH TANGGA) GUNA MENINGKATKAN KENYAMANAN DAN KESEHATAN WARGA PERUMAHAN CITRA GARDEN
}

\author{
Mirza Ghulam R. ${ }^{1)}$, Herman Yuliandoko ${ }^{2)}$, M. Shofi'ul Amin ${ }^{3)}$ \\ 1) 2) 3) Staf Pengajar Program Studi Teknik Sipil Politeknik Negeri Banyuwangi \\ mirza@poliwangi.ac.id.
}

\begin{abstract}
Abstrak
Perumahan Citra Garden merupakan perumahan yang pertama kali berdiri di desa Lemahbang Dewo. Perumahan ini berada disepanjang saluran irigasi yang mengairi sawah disisi timur dan sisi barat perumahan. Saluran irigasi ini merupakan satu-satunya jalur pengairan untuk areal persawahan warga. Saluran irigasi ini menjadi salah satu area banjir pada musim penghujan. Selain karena debit air yang melimpah, sampah pertanian dan sampah rumah tangga yang menyumbat saluran irigasi menjadi penyebab utama banjir di perumahan Citra Garden.
\end{abstract}

Banjir yang terjadi selalu menghasilkan tumpukan sampah pertanian dan sampah rumah tangga. Hal ini menunjukkan bahwa tumpukan sampah tersebut telah menyumbat saluran irigasi sehingga mengakibatkan limpasan air menggenangi jalan disepanjang jalur irigasi. Tumpukan sampah ini menunjukkan perilaku warga yang tidak tepat dalam upaya menjaga lingkungan. Sampah yang dominan menyumbat saluran adalah sampah pertanian dan sampah rumah tangga, yaitu berupa plastik bekas penutup tanah untuk penyemaian tanaman, plastik bungkus makanan, pampers dan lain sebagainya. Dalam hal ini perlu dibuatkan penyaring sampah pada hulu saluran irigasi untuk mencegah sampah dari luar perumahan masuk ke saluran irigasi di perumahan lalu menyumbat jalur irigasi dan akhirnya menggenangi jalan disepanjang jalur irigasi.

Masyarakat Desa Lemahbang Dewo Kecamatan Rogojampi, khususnya warga perumahan Citra Garden membutuhkan perbaikan sarana prasarana saluran air hujan sebagai persiapan menghadapi musim penghujan. Diperlukan terobosan-terobosan untuk bisa menormalisasi saluran eksisting dan menjaga ketersediaan air tanah di lingkungan perumahan. Dengan diperbaikinya saluran air irigasi dan saluran air hujan, gangguan yang selama ini mengganggu aktifitas warga perumahan berkurang. Dengan dibaginya air pada saluran irigasi, over volume yang terjadi pada saluran irigasi akan berkurang. Saluran juga memerlukan penyaring sampah untuk mencegah sampah masuk kedalam gorong-gorong, sehingga kemungkinan terjadinya penyumbatan saluran akan dapat dihindari. Selain itu perlu adanya saluran keliling untuk mengalirkan air hujan ke saluran utama.

Kata Kunci : Perumahan Citra Garden, Banjir, Lemahbang Dewo.

\section{PENDAHULUAN}

Perumahan Citra Garden merupakan perumahan yang pertama kali berdiri di desa Lemahbang Dewo. Perumahan ini berada disepanjang saluran irigasi yang mengairi sawah disisi timur dan sisi barat perumahan. Saluran irigasi ini merupakan satu-satunya jalur pengairan untuk areal persawahan warga. Saluran irigasi ini menjadi salah satu area banjir pada musim penghujan. Selain karena debit air yang melimpah, sampah pertanian dan sampah rumah tangga yang menyumbat saluran irigasi menjadi penyebab utama banjir di perumahan Citra Garden. Lokasi saluran irigasi ditunjukkan pada Gambar 1. Banjir yang terjadi selalu menghasilkan tumpukan sampah pertanian dan sampah rumah tangga. Hal ini menunjukkan bahwa tumpukan sampah tersebut telah menyumbat saluran irigasi sehingga mengakibatkan limpasan air menggenangi jalan disepanjang jalur irigasi.

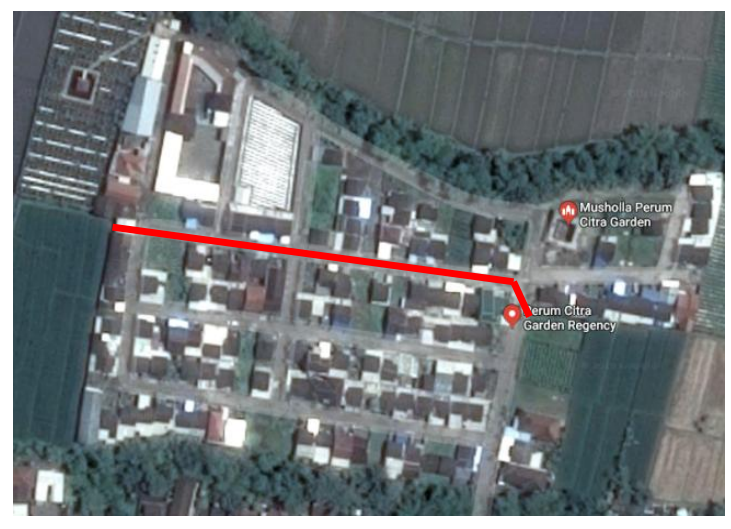

Gambar 1 Jalur irigasi (sumber : Google map, 2018)

Sampah yang dominan menyumbat saluran adalah sampah pertanian dan sampah rumah tangga, yaitu 
berupa plastik bekas penutup tanah untuk penyemaian tanaman, plastik bungkus makanan, pampers dan lain sebagainya.

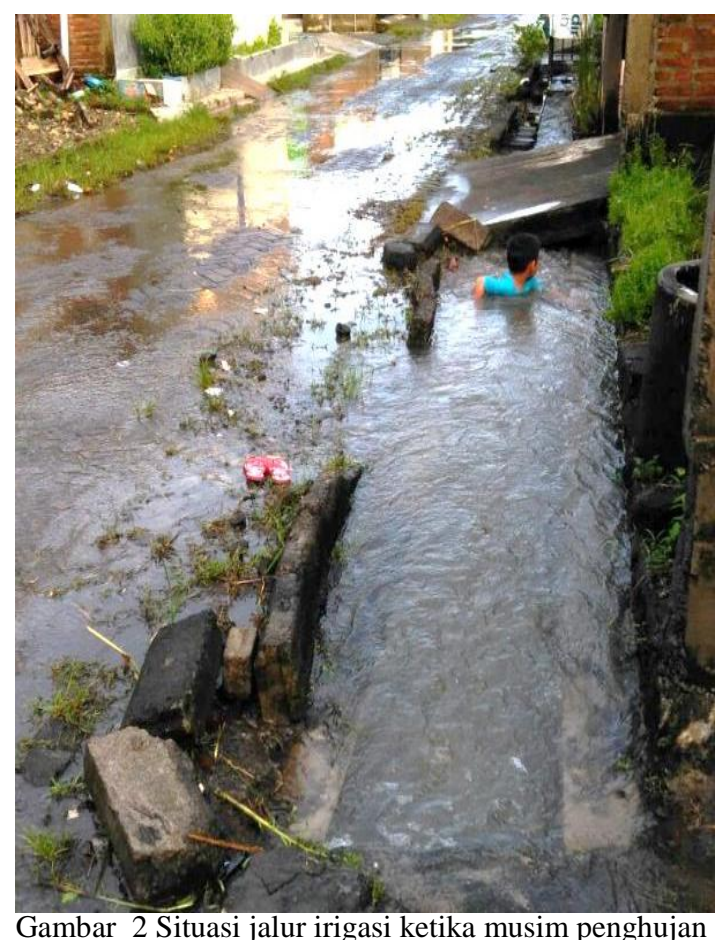

Dalam hal ini perlu dibuatkan penyaring sampah pada hulu saluran irigasi untuk mencegah sampah dari luar perumahan masuk ke saluran irigasi di perumahan lalu menyumbat jalur irigasi dan akhirnya menggenangi jalan disepanjang jalur irigasi. Situasi jalur irigasi ketika musim penghujan ditunjukkan pada Gambar 2.

\section{II.TARGET DAN LUARAN}

Target yang akan dihasilkan dalam penerapan iptek ini adalah dengan menormalisasikan saluran dan memaksimalkan resapan tanah terhadap air hujan. Solusi tersebut didapatkan dari penelitian yang sudah pernah dilakukan.

Luaran dari kegiatan ini adalah Penerapan Teknologi Tepat Guna sebagai implementasi penelitian sebelumnya yaitu Normalisasi saluran, Membuat biopori pada dasar saluran, Membuat saluran penghubung untuk membagi jalur irigasi dan Menutup hulu saluran dengan penyaring sampah.

Produk luaran pada kegiatan pelatihan antara lain: 1. Publikasi pada media masa cetak lokal, 2. Publikasi pada jurnal, 3. Penerapan Teknologi Tepat Guna sebagai implementasi penelitian sebelumnya.

\section{III.METODE PELAKSANAAN}

Pada kegiatan ini dilakukan beberapa tahapan dan alur pelaksanaannya yang meliputi survey lokasi, pemeriksaan lokasi eksisting, perbaikan infrastruktur dan penerapan teknologi tepat guna.

\section{Survey}

Dalam tahapan ini dilakukan beberapa survey dan penentuan lokasi permasalahan, antara lain: 1 . Survey sarana (lokasi) pengabdian. Lokasi pengabdian dilakukan di Perumahan Citra Garden Desa Lemahbang Dewo, Kecamatan Rogojampi, Kabupaten Banyuwangi. 2. Mempersiapkan sarana dan prasarana yang dibutuhkan, seperti: mempersiapkan laboratorium /workshop untuk kegiatan pengabdian, melakukan persiapan alat dan bahan yang digunakan, persiapan tenaga teknisi dan menyiapkan alat-alat yang dibutuhkan dalam pengabdian masyarakat.

\section{Pemeriksaan As Built Drawing}

Dalam tahapan ini dilakukan pemeriksaan terhadap gambar hasil pekerjaan konstruksi yaitu As Built Drawing. Pemeriksaan As Built Drawing memberikan informasi mengenai konstruksi saluran yang berada dibawah jalan yang tidak terlihat dari permukaan tanah. Pada tahapan ini akan memberikan petunjuk tentang metode perbaikan yang harus dilakukan. Gambar as built drawing ditunjukkan pada Gambar 3.

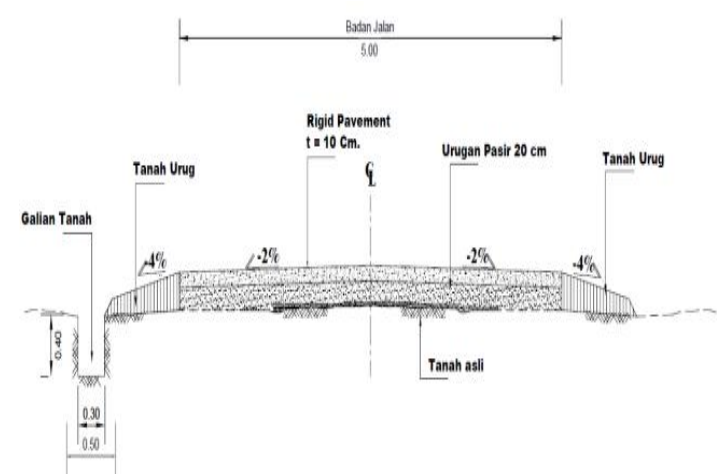

Gambar 3 Potongan melintang jalan eksisting

\section{IV.HASIL DAN PEMBAHASAN}

Pelaksanaan kegiatan dilakukan dalam beberapa kegiatan, antara lain: 1. Kegiatan pra pelaksanaan adalah survey dan koordinasi dengan pihak desa, dalam hal ini diwakili oleh sekretaris desa. Survey dan koordinasi dilakukan untuk mendapatkan ketepatan target pelaksanaan dan kebutuhan masyarakat sekitar. 


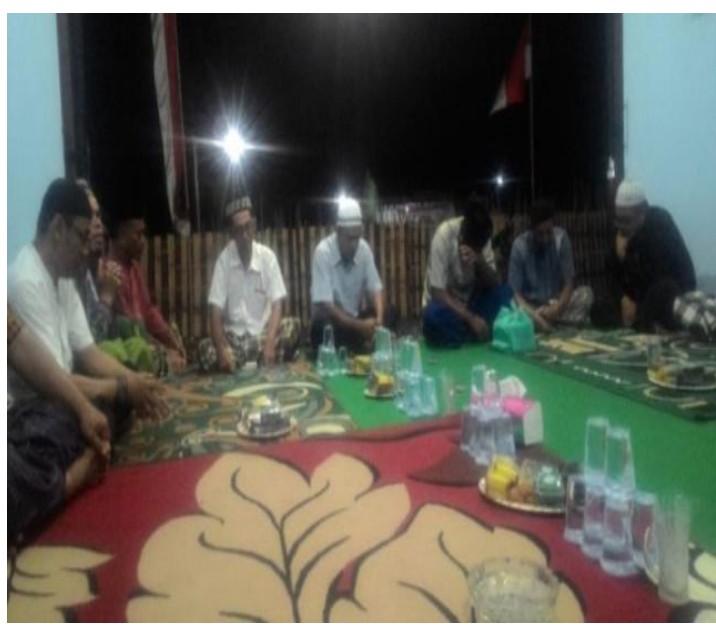

Gambar 4 Koordinasi pelaksanaan kegiatan

Koordinasi dengan perangkat desa dan warga dilakukan dalam beberapa pertemuan. Dokumentasi kegiatan ditunjukkan pada Gambar 4.

Setelah koordinasi dilakukan, target pekerjaan dan rencana kerja mulai disusun. Rencana tersebut dituangkan dalam gambar kerja sebagai dasar pekerjaan normalisasi dan perbaikan saluran eksisting. Kondisi eksisting didesain dengan drainase melintang jalan dengan tambahan biopori. Gambar perencanaan saluran penghubung disajikan pada Gambar 5.

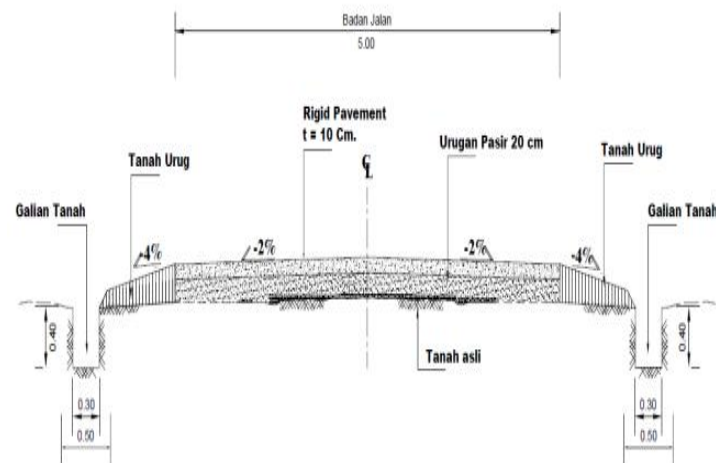

Gambar 5 Rencana saluran penghubung

Setelah gambar kerja disusun, kegiatan selanjutnya adalah dengan melakukan normalisasi saluran. Saluran eksisting dibersihkan dan dikembalikan fungsi dan dimensinya seperti semula. Dimensi saluran diperbaiki dan sampah serta sedimentasi yang terdapat pada saluran diangkat. Pelaksanaan kegiatan ini tidak bisa dilakukan dalam sekali kegiatan. Kondisi eksisting saluran pada sisi utara ditunjukkan pada Gambar 6 dan kondisi saluran setelah dilakukan normalisasi pada titik yang sama ditunjukkan pada Gambar 7 .

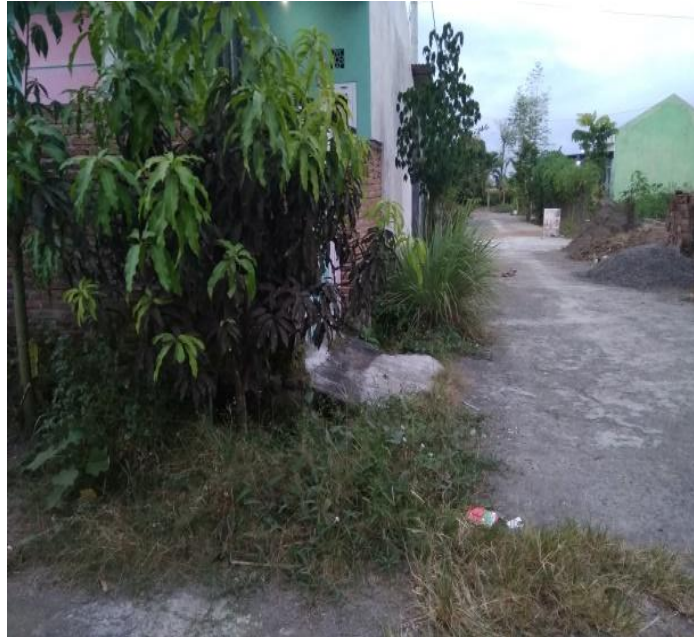

Gambar 6 Kondisi eksisting saluran sisi utara

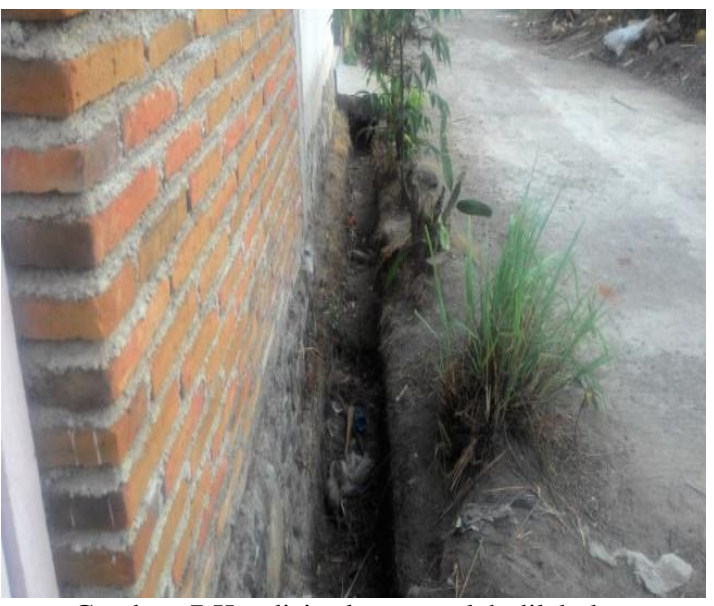

Gambar 7 Kondisi saluran setelah dilakukan normalisasi

Kondisi eksisting saluran pada sisi sungai ditunjukkan pada Gambar 8, dan kondisi saluran setelah dilakukan normalisasi pada titik yang sama ditunjukkan pada Gambar 9.

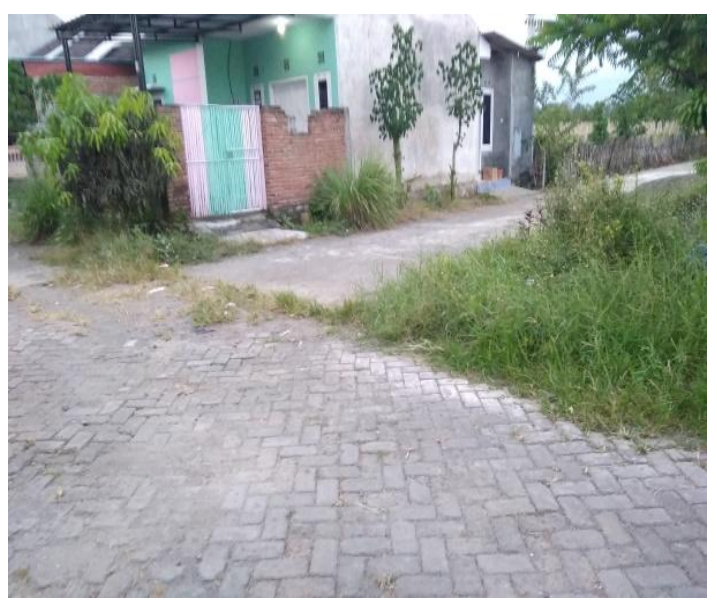

Gambar 8 Kondisi eksisting saluran pada sisi sungai 


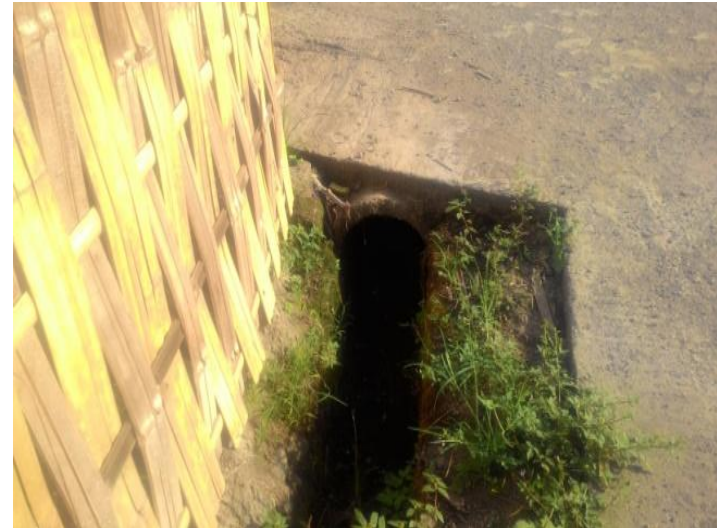

Gambar 9 Kondisi saluran setelah dilakukan normalisasi

Selanjutnya Jalan beton dibongkar sebagaimana rencana yang tertuang pada gambar kerja. Setelah pembongkaran, selanjutnya tanah digali sedalam $56 \mathrm{~cm}$ dengan dilakukan penyesuaian elevasi saluran sebesar $1 \%$. Kegiatan persiapan galian saluran ditunjukkan pada Gambar 10, Gambar 11 dan Gambar 12.

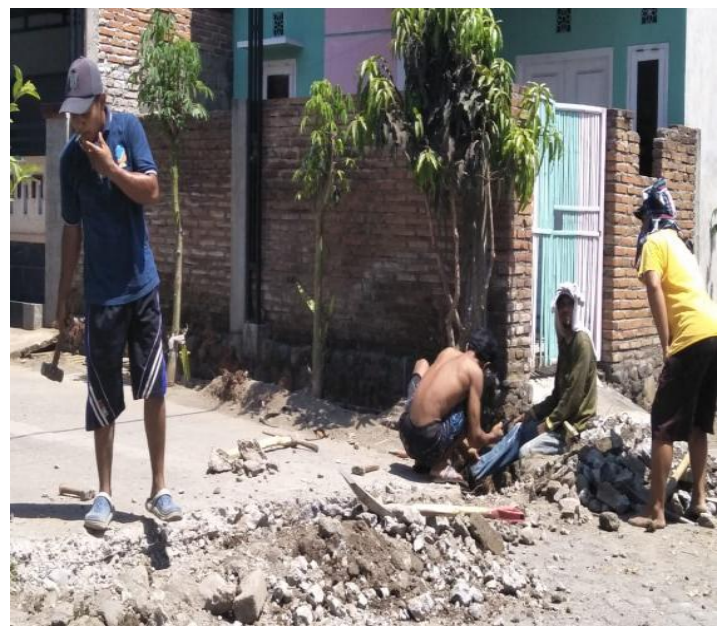

Gambar 10 Pengupasan jalan beton untuk persiapan saluran melintang jalan

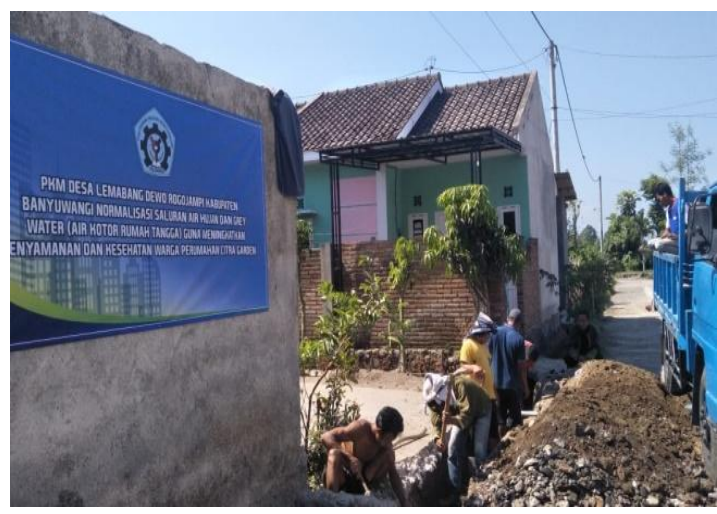

Gambar 11 Galian jalan beton untuk membuat saluran melintang jalan

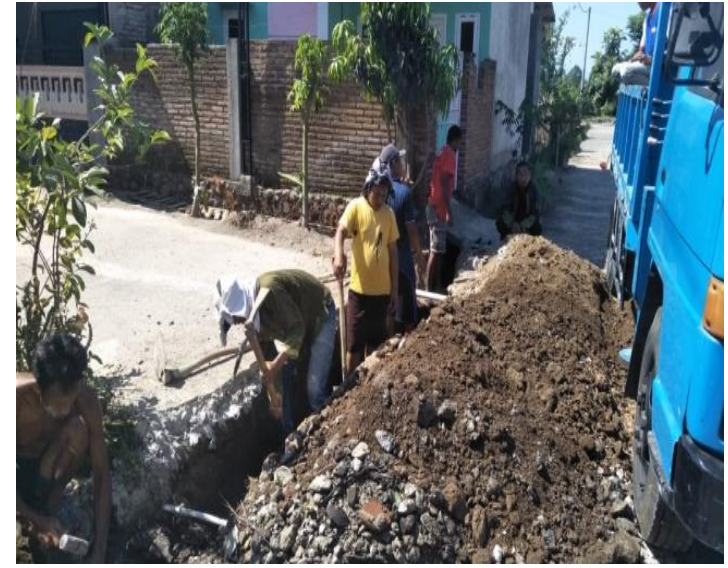

Gambar 12 Finalisasi galian tanah dibawah lapisan beton

Setelah galian siap, selanjutnya pasir urug dihampar setebal $10 \mathrm{~cm}$ pada galian tanah yang telah disiapkan sebelumnya. Urugan pasir berfungsi sebagai peredam dan pengunci elevasi $U$-ditch.

Setelah saluran siap, maka $U$-ditch dengan dimensi $40.40 \mathrm{~cm}$ diturunkan dan diposisikan kedalam saluran sesuai dengan rencana sebagaimana tertuang pada gambar kerja. Proses erection $U$-ditch ditunjukkan pada Gambar 13, Gambar 14, Gambar 15 dan Gambar 16.

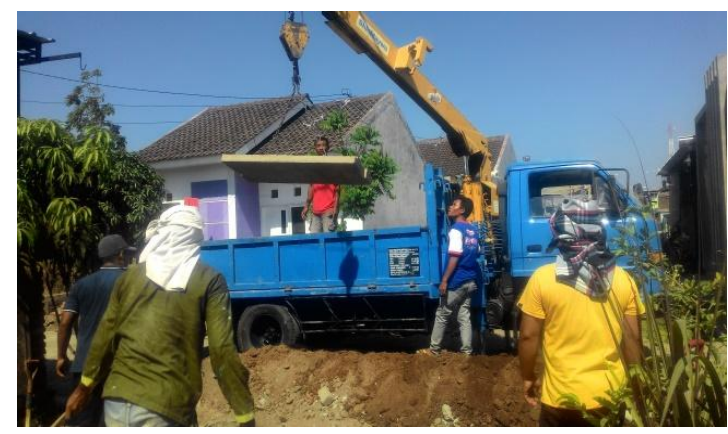

Gambar 13 Proses penurunan $U$-ditch dari truk menggunakan crane

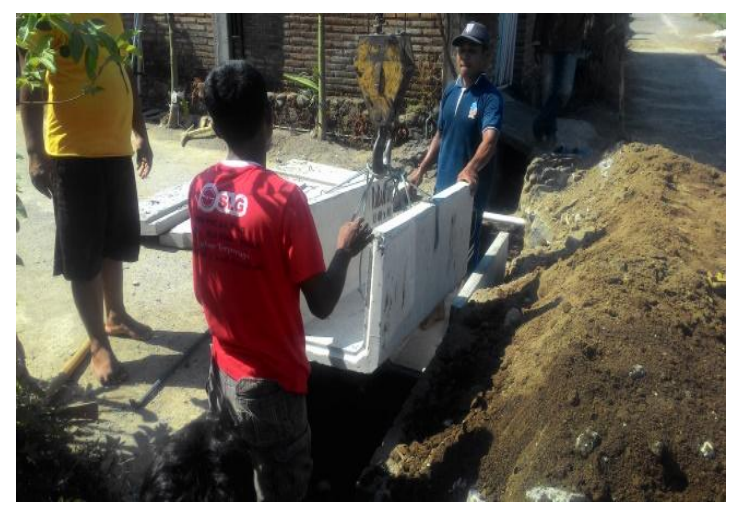

Gambar 14 Proses erection U-ditch pada saluran 


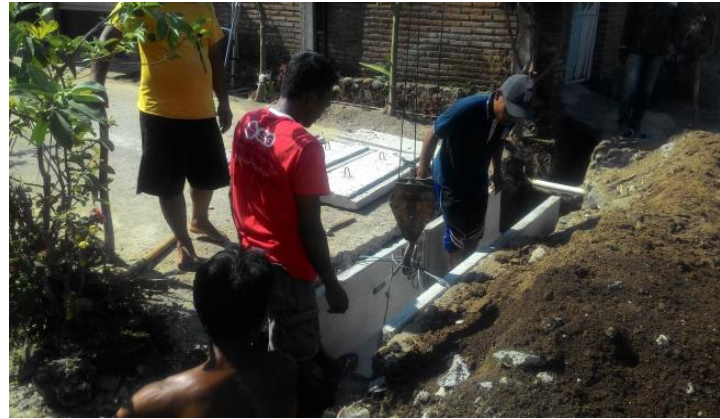

Gambar 15 Pengecekan elevasi saluran setelah $U$-ditch dipasang

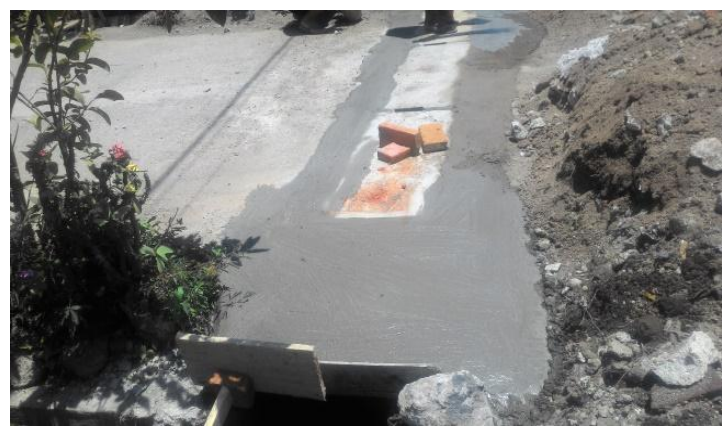

Gambar 16 Finalisasi pemasangan $U$-ditch

Pada mulut gorong-gorong, saluran irigasi dilengkapi dengan filter/penyaring berupa jeruji besi untuk menahan/menyaring sampah agar tidak masuk kedalam gorong-gorong dan menyumbat gorong-gorong. Pemasangan penyaring sampah pada mulut gorong-gorong ditunjukkan pada Gambar 17.

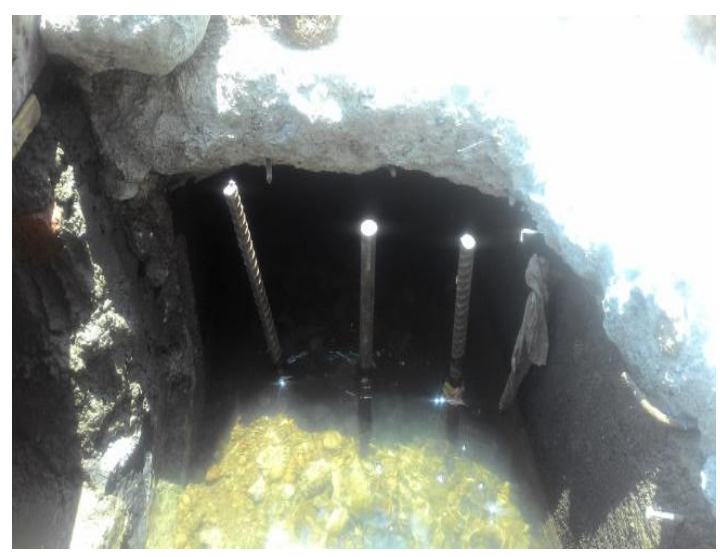

Gambar 17 Pemasangan penyaring sampah pada mulut gorong-gorong eksisting

Pada mulut saluran penghubung dilengkapi dengan pintu air untuk mengatur pembuangan air ketika terjadi over volume pada saluran irigasi. Proses pelaksanaan kegiatan pembuatan saluran penghubung ditunjukkan pada Gambar 18.

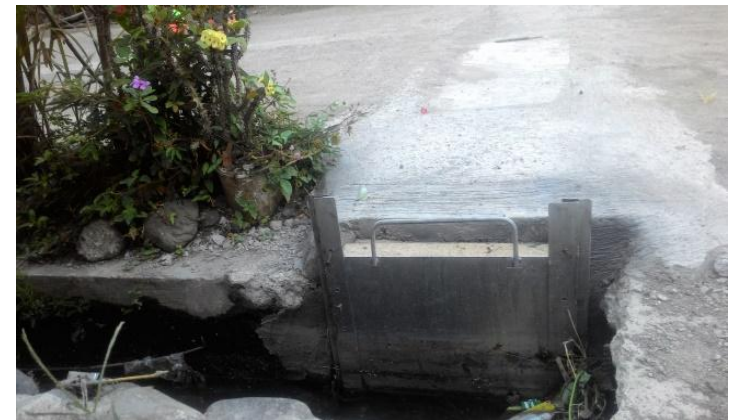

Gambar 18 Pintu air pada saluran penghubung

\section{KESIMPULAN DAN SARAN}

PKM Desa Lemahbang Dewo Rogojampi Kabupaten Banyuwangi Normalisasi Saluran Air Hujan dan Grey Water (Air Kotor Rumah Tangga) guna Meningkatkan Kenyamanan dan Kesehatan Warga Perumahan Citra Garden memberikan wawasan kepada warga Lemahbang Dewo mengenai pentingnya menjaga kebersihan saluran drainase. Selain itu, kegiatan pengabdian pada kawasan Perumahan Citra Garden Desa Lemahbang dewo merupakan aplikasi hasil penelitian dan memberikan pemahaman kepada masyarakat dalam menanggulangi banjir dan menghindari banjir dalam skala besar serta menjaga keseimbangan lingkungan sekitar.

Dengan dibaginya air pada saluran irigasi, over volume yang terjadi pada saluran irigasi akan berkurang. Pemasangan penyaring sampah pada mulut gorong-gorong untuk mencegah sampah masuk kedalam gorong-gorong, sehingga kemungkinan terjadinya penyumbatan pada gorong-gorong dapat dihindari.

\section{DAFTAR PUSTAKA}

[1] Ching D.K. Francis,dkk. 2008. Ilustrasi Konstruksi Bangunan. Jakarta: Erlangga

[2] Juwana S. J. 2005. Panduan Sistem Bangunan Tinggi. Jakarta: Erlangga

[3] Noerbambang Sofyan M. 1991. Perancangan dan Pemeliharaan Sistem Plumbing. Jakarta:PT. Pradnya Paramita

[4] Pijil.1990.Ringkasan Ilmu Bangunan Jilid 1 dan 2, Jakarta:Erlangga

[5] Standart Nasional Indonesia (SNI) 15-2049-2004. Semen Portland. 